Research Article

\title{
Analysis of deaf students understanding math concepts in the topic of geometry (rectangle shape): A case study
}

\author{
Andi Husniati1,2, I Ketut Budayasa3, Dwi Juniati4, Carol Le Lant5
}

\section{Article Info}

Received: 13 April 2020

Revised: 27 June 2020

Accepted: 30 August 2020

Available online: 15 Sept 2020

Keywords:

Cognitive domain

Deaf student

Geometry

Inclusive education

Learning mathematics

Special education

2149-360X/ C 2020 The Authors. Published by Young Wise Pub. Ltd. This is an open access article under the CC BY-NC-ND license

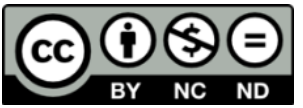

\begin{abstract}
Students with special needs are students who need special treatment, especially in terms of learning, apart from being limited in communication and knowledge; they also have limitations in learning mathematics. One type of students with disabilities is deaf students. The purpose of this study was to describe how students understand mathematics, especially geometry material (shape rectangle) using cardboard media. The research subjects consisted of one female student with hearing loss seventh grade at the Inclusive School in Gresik Jawa Timur Indonesia. The selected research subjects are students with moderate hearing impairment to enable an interaction between researcher and subject. The research instrument uses video records to see how the subject understands (geometry) rectangular shapes through cardboard media and when students work on a given problem, photos to refer the results of student work, and written test in worksheets to get the data on student 'work. The data analysis technique used descriptive analysis by describing students' understanding in understanding rectangular shapes using cardboard media. The results showed that using visual objects students found it easier to identify geometric shapes based on their physical appearance. However, students had difficulty in defining rectangular shapes and did not find a relationship between rectangular shapes and square shapes. Deaf students in this study generally use the different ways that the students generally in expressing his understanding of the shapes rectangle.
\end{abstract}

\section{To cite this article:}

Husniati, A., Budayasa, I.K., Juniati, D., \& Lant, L.C. (2020). Analysis of Deaf Students Understanding Math Concepts in the Topic of Geometry (Rectangle Shape): A Case Study. Journal for the Education of Gifted Young Scientists, 8(3), 1213-1229. DOI: http://dx.doi.org/10.17478/jegys.780213

\section{Introduction}

Mathematics is one of the fields of science that trains students to think critically, systematically, logically, creatively, and the ability to work together effectively, because mathematics has a clear structure between its concepts (Misu et al. 2019). It makes mathematics one of the basic sciences, both applied aspects and aspects of reasoning have a significant role in the effort to master science and technology (Rosdiana et al. 2019; Ningsih et al. 2019). These abilities can be obtained if in mathematics learning the conceptual understanding is embedded in the minds of students. Skemp (1976) states that to conceptual, relational understanding is a need, not memorization, relational understanding is specific knowledge obtained by finding the relationship between one concept and another. Conceptual knowledge strength lies in the ability of individuals to combine and connect several different experiences and classify (Raghubar et al. 2010; Achmetli et al. 2019; Ling et al. 2019). The more abstract a concept is, the higher the power of the concept to be combined and connected with various experiences (Akuba et al. 2020; Curto Prieto, 2019).

\footnotetext{
1 Student in Doctoral Program of Mathematics Education, State University of Surabaya, Indonesia E-Mail: husniatia.husniati@mhs.unesa.ac.id Orcid No: 00000001-6721-8256.

2 Department of Mathematics, Universitas Muhammadiyah Makassar - Indonesia, E-mail: andihusniati@unismuh.ac.id, Orcid No: 0000-0001-6721-8256

3 Department of Mathematics, State University of Surabaya - Indonesia, E-mail: ketutbudayasa@unesa.ac.id. Orcid No: 0000-0002-5066-859X

4 Department of Mathematics, State University of Surabaya - Indonesia, E-mail: dwijuniati@unesa.ac.id, Orcid No. : 0000-0002-5352-3708

5 College of Education, Psychology and Social Work, Flinders University - Australia, E-mail: carol.lelant@flinders.edu.au, Orcid No. : 0000-0003-1815-4203
} 
According to Skemp (1976) and Dewi (2020), a person's understanding of both procedural and conceptual knowledge is influencing by cognitive structures in the mental or mind of the individual concerned. He argues that the learning approach can use two assumptions. The first assumption is an individually acquired knowledge utilizing active interaction between individuals who are learning with the environment. Thus, changing individual behaviour in the expected direction. The second assumption is that individuals construct knowledge by relating the information found with the knowledge they have. Duffin \& Simpson (2002) suggests the characteristics of understanding is the student's ability to: (1) solve the problem, (2) to explain the concept, means students can revive what had been communicated to him; (3) using concepts in new content; (4) develop some of the consequences of the existence of a concept, can mean that students understand a concept consequently students to have the ability to solve every problem with correctly.

The success of mathematics in schools, as well as planting concept, is also influenced by many factors (Anggareni et al. 2010). One of them is environmental factors, both the social environment and the natural environment through the ability of the senses. In the social environment, it is how a person can communicate with others so that what is conveying can be understood while in the natural environment, the human senses generally consist of the senses of sight, hearing, taste, touch and smell (Mudjiyanto, 2018). Even though each sense has unique characteristics and characteristics, in work, it requires cooperation and integration between the senses of sight, hearing, taste, touch and smell (Yuliana et al. 2019). The purpose of cooperation between the senses is to get recognition, gain understanding, or complete and full meaning of the objects in their environment, including in a math problem. One topic that desperately needs math is understanding the concept of geometry. Geometry is a part of mathematical content that is taught at every level of education. Clement \& Battista (2004) stated that the objectives of learning geometry include developing logical thinking, developing spatial intuition, imparting knowledge to learn mathematics further and interpreting arguments mathematically (Ghani \& Zulkarnaen, 2020; Tahmir et al. 2019).

But the reality in the field shows that the geometry of student learning outcomes can be improved. Students experience the difficulty in learning geometry at almost all levels of education, such as problems related to measurement, line problems, the relationship between flat shapes and spatial shapes (Rosdiana et al. 2019). If students in general still have difficulty learning geometry, of course, deaf students also experience difficulties because what deaf students catch is less than students in general. According to Gimenez et al. (2005), students with hearing impairment have difficulty with geometry material in generalizing the properties of shapes; it takes a longer time than other students. According to Akram et al. (2013) defines deafness as follows: Hearing impairment a generic term indicating a hearing disability that may range in severity from mild to profound it concludes hearing disability preclude successful processing of linguistic information through audition, with or without a hearing aid. A hard of hearing is one who generally with the use of hearing aid, hs residual hearing sufficient to enable successful processing linguistic information through audition.

Based on an interview about the experience of an individual deaf mentor teacher in special schoolsCendrawasih Makassar, Many teachers complain about the difficulty of deaf students in the material of flat geometric shapes. Students find it challenging to distinguish names between shapes. They assume everything is the same based on the shape they observe. While the results of classroom observation by the author in SLB Patronage South Sulawesi province in 2014 when teachers teach the material flat geometry circles that there are deaf students understand the usual circles based on what they encounter in everyday life. Even though they took a long time to give their answers, some said that the circle was like a bicycle tire, some showed their shirt buttons, the steering wheel of the car, they used sign language and practised with their body movements the tad imagined object.

Nevertheless, some of them did not understand when asked why they could not reveal the reason. But this shows that the students' minds have reflected the concept of a circle. However, from other geometric shapes, they still have difficulty distinguishing, for example, a square, a rectangle, a rhombus, a parallelogram, a trapezoid, they answer that it is a rectangle. Similarly, the results of interviews with teachers of mathematics and teachers' guidance and counselling in schools Inclusion August 2018 stated that deaf students have no school that requires an explanation repeatedly to provide an understanding of the subject matter is mainly the subjects of mathematics in general, even for "the word" particular requires explanation using the media

The cognitive development of deaf students tends to be hampered when compared to students in general. As a result, solving math problems takes a long time. It is due to the cognitive development is not only closely related to 
intelligence or intelligence, but also a person's hearing ability and communication for deaf students in general in addition to hearing loss also affects the ability to communicate. Through all this sensory stimuli or information will be accepted for the next transmitted to the brain.

Based on preliminary data obtained from mathematics teachers at individual schools for the deaf in the city of Makassar and the Assisted Special Schools in South Sulawesi Province. The two mathematics teachers at the Special School, and the Inclusion Junior High School teacher and the Guidance and Counseling teacher said that deaf students also have an intense curiosity to learn mathematics. It's just that they are a little slow in understanding the material due to hearing loss and communication skills so that the teacher repeats the topic taught. The results of the flat geometry test conducted by the author on Friday, March 18 to two students of the Gresik special school; The results showed that from the instrument given the two students answered according to their abilities, and both answered with satisfactory results because of the three items given all of them were able to answer although not one hundred percent correct with a long time. However, they can express their opinion through writing or by sign language and lip movements. The grasp of the different students can cause it because of the ability to hear very closely related to communication skills. There is a strong suspicion that students may be wrong in responding to what is conveyed by the teacher.

Several studies have examined the understanding of concepts in mathematics learning. Beller \& Gafni (2000) and Hergovich et al. (2004) stated that in general, male mathematics achievement was better than female mathematics achievement. Else-quest et al. (2010) argue that men outperform women in solving complex problems. The two researchers compared the achievements of men and women who were not disabled. In contrast, the researchers had not found the results of research that compared the achievements and understanding of male and female deaf students on a mathematical concept based on gender.

This study is a researcher's initial study to develop it to the next stage (dissertation). The researcher is interested in examining the perception of the mathematical definition of students with hearing loss with the theme of the quadrilateral definition from the explanation described. The purpose of this study is to provide an initial description of the ability of deaf students in terms of understanding concepts.

\section{Problem of Study}

The problem in this study is formulated in the form of a question of how capable the deaf students understand the concept of rectangles, namely rectangular and square shapes?

\section{Method}

\section{Research Model}

This study aims to determine the understanding profile of deaf students on the concept of rectangles, namely rectangular and square shapes. This type of research is descriptive exploratory with a qualitative approach (Merriam, 2009). This research was conducted explorative with deaf students regarding what the students displayed through sign language, specific pictures or symbols when expressing their understanding of the rectangular and square concepts, so the research was descriptive. Furthermore, the data described what their experience to gain an overview understanding of deaf students on the concept of the rectangle and square shape through interviews in a specific time and continuously. Qualitative data has more advantages compared to quantitative data because qualitative data is richer in terms of description and explanation (Huberman, Miles \& Saldana, 2013). A qualitative approach was used because the data collection was natural and rooted in the form of words both spoken and using sign language, gestures and facial expressions and gestures and facial expressions and written answers. The general form of qualitative data is in the form of words derived from observations, interviews or documents.

\section{Participants}

The subjects in this study were students with moderate hearing impairment at Inklusi Junior High School who sat in grade VII with the consideration that geometry topic had been introduced at the previous level, namely in elementary school and was still part of the topic studied in grade VII. In addition, students of class VII is deemed able to communicate and adequate to be interviewed in order to investigate and uncover the understanding in the shape of the rectangle and square.

Determination of a research subject was preceded by classifying deaf students who have an IQ in the 80-85 range and deafness are relatively equal then assign one person each female subjects with moderate hearing impairment. Researchers also consider input from a school math teacher. Then the selected characters, including the 
ability to adapt and communicate with others based on classroom observations and information from the teacher in the classroom. It is because the teacher knows better about the character of his students better. Thus, subjects in this study 1 woman.

Furthermore, the research subject was abbreviating as SKS (moderate deaf subject). The selection of the research location was, of course, through specific considerations. It is because some of the schools contacted did not have moderate deaf students; most students were deaf, so researchers looked in various places until they finally got the subject at the Inclusion Junior High School

\section{Data Collection Tools}

The researcher, as the main instrument, collected data using supporting instruments in the form of rectangular questions and interview guides. Data was collected by using task-based interviews with a think-aloud method. The subject worked on the quadrilateral problem by writing down the answer on the provided answer sheet accompanied by expressing what was being thought at that time in his style. If students do not express what they are thinking, the researcher can interview the subject by asking what the subject is thinking of answering the test questions.

The subjects in this study were students with moderate hearing disabilities who belonged to children with special needs. Then the data retrieval process cannot be identified as the subject of research on normal students. Deaf students cannot do a job for as long as normal students, and sometimes deaf students want to play quickly and various other reasons. If this happens, the data collection can be continued on the next day until the student is willing to work without coercion. At the time of data collection, researchers will be accompanied by a teacher; it is necessary to enable researchers to communicate with the subjects to anticipate mistakes in communicating with sign language.

The data collection procedure is carried out by the following steps: (1). The subject matter of waking a given rectangle. (2). At the initial stage of completing the shape-up problem-solving test, subjects were asked to read and at the same time, understand the questions that had been given. (3). Conducting semi-structured interviews with spoken language and gesture and the observation of the components of understanding. The results of interview transcripts, observations and written answers were used to explore students' conceptual understanding (4).Triangulation. The triangulation used in this research is time triangulation by comparing the data from the written answers and the data from the second interview with different time intervals. (5). All activities of the subjects in the time of data collection were recording using audiovisual instruments as for the indicator to be achieved an understanding of the concepts presented in Table 1.

Table 1.

Concept understanding indicators used

\begin{tabular}{ll}
\hline \multicolumn{1}{c}{ Category } & \multicolumn{1}{c}{ Indicator } \\
\hline Interpreting & $\begin{array}{l}\text { The subject interprets several images and surrounding objects as representations of rectangular } \\
\text { and square shapes }\end{array}$ \\
Exemplifying & The subject gives an example in the form of a rectangular shape and a square shape \\
Classifying & The subject classifies objects in the category of rectangular and square shapes \\
Summarizing & $\begin{array}{l}\text { The subject makes a statement regarding the characteristics of a rectangular shape and a square } \\
\text { shape }\end{array}$ \\
Inferring & The subject concludes related to the meaning of a rectangular shape and a square shape \\
Comparing & The subject determines the similarities and differences of the rectangular and square shapes \\
Explaining & $\begin{array}{l}\text { The subject constructs a causal relationship between the concept of a rectangular shape and a } \\
\text { square shape. }\end{array}$
\end{tabular}


Table 2.

Interview Form

Interview guidelines

1. Interview Objectives

This interview aims to reveal the understanding profile of deaf students in completing rectangular and square shapes

2. Interview Method

Interview method used is not a structured interview based on a problem-solving task

3. Implementation of the Interview

The interview questions are adapted to the problem-solving process carried out by the subject, so they do not have to be the same as the questions in this guide but still refer to the purpose of the interview.

A. Interpreting category

1. Show the shapes that include the rectangular and square shapes in the image

2. Find objects in your environment that look the same as a rectangle and a square

3. Give your reason why you said it looked the same as a rectangular shape

4. Give your reasons why you said the object looks the same as a square shape

B. Exemplifying category

1. Give an example in the form of a rectangular shape that is different from the image above

2. Give reasons why the shape you are drawing is rectangular

3. Give an example in the form of a square shape that is different from the image above.

4. Give reasons why the shape you are drawing is square.

C. Classifying category

1. Write down the code that has been given in the column provided

2. Give your reasons why to write specific code in that column.

D. Summarizing category

1. Identify and explain the characteristics of the rectangular shape.

2. Specify and write down the characteristics of square shape

E. Inferring category

1. What do you think is a rectangular shape

2. What do you think is a square shape

F. Comparing category

1. What is the difference between a rectangular shape and a non-rectangular shape

2. What is the difference between a square shape and a non-square shape

3. What is the difference between a rectangular shape and a square shape

4. What is the equation for a rectangular shape and a square shape

G. Explaining category

1. Is a rectangular shape can also be called a rectangular shape? why

2. Is a square shape also called a rectangular shape? why

The validator validated the interview instrument according to his expertise, namely one mathematics education expert, two mathematics education teachers at Inclusive Junior High School, a guidance and counseling teacher, a mathematics education lecturer.

\section{Procedure}

Procedures are activities that will be carried out from preparation to preparation of research results in the form of a report. These activities are described as 1) Preparation stage. This stage includes the following activities: (a) determining research locations, surveying research locations and making research permits (b) preparing instruments (c) preparing data collection tools (tools for recording data); 2) Implementation stage: a. An explanation of the research activities of meeting with the principal, teacher mathematics, guidance and counselling teachers give an explanation by the researchers about the conduct of the study. The explanation includes the title of the study, the intent and purpose of research, time and procedures implementation of the study. d. Instrument development, e. Selection of research subjects The selection of research subjects was carried out as previously described. d. Data collection; 3) Analysis Phase: In the analysis stage, the activities undertaken are to follow the steps of data analysis which include data categorization, reduction, presentation, interpretation, and conclusion drawing; 4) Reporting: Activities undertaken at this stage include the preparation of research reports in the form of a dissertation. 


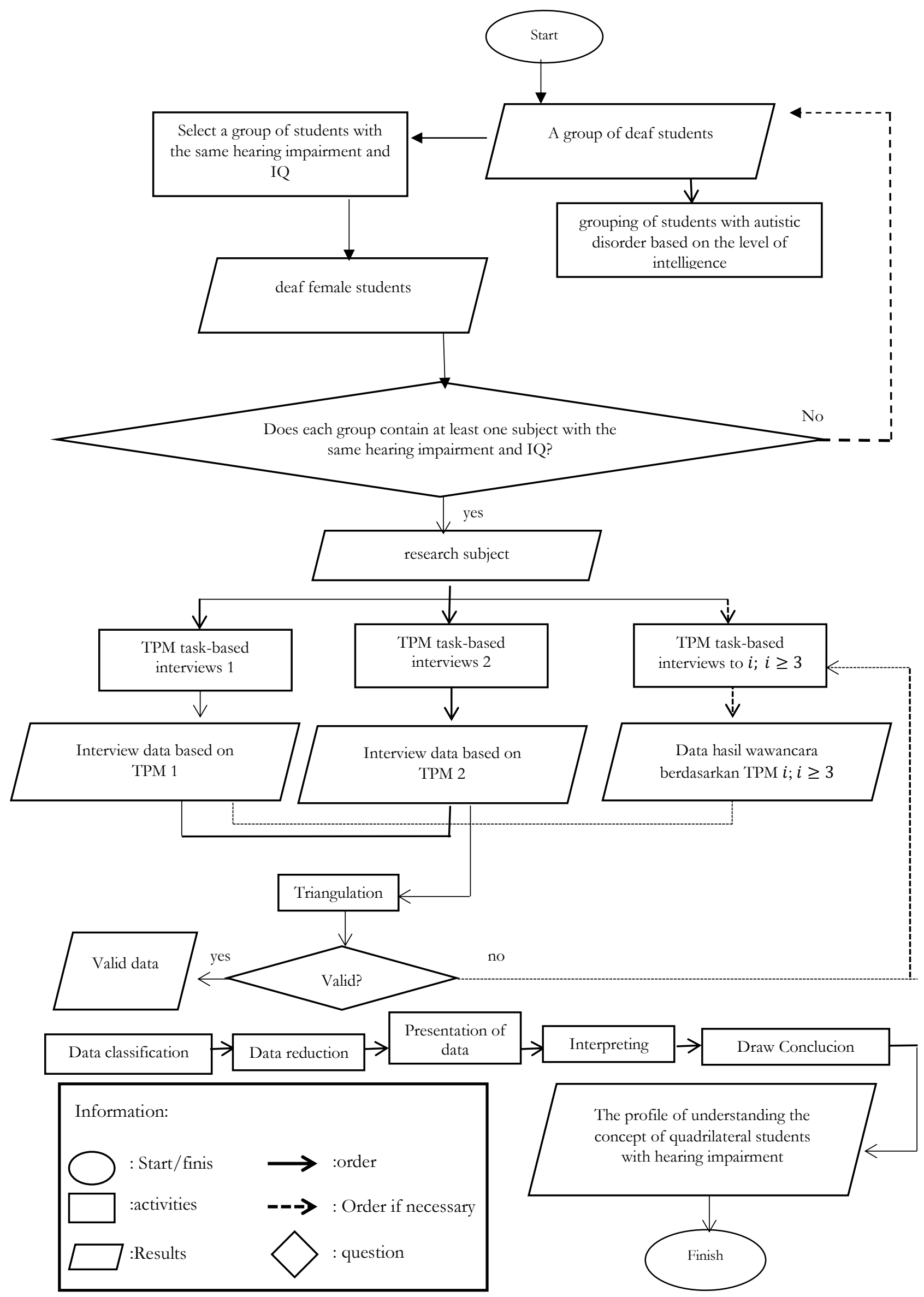

Figure 1. 


\section{Stages of research procedures}

\section{Data Analysis}

The data analysis technique used in this research is a qualitative analysis which refers to the data analysis model of Miles \& Huberman (1994). Activities in data analysis are data categorization, data reduction, data display, and conclusion drawing/verification (Miles \& Huberman, 1994). These three data analysis activities are not hierarchical but are a chain of activities that interact with each other starting from before, during and after data collection.

To test the credibility of the data or confidence in the data obtained is used triangulation. The triangulation used in this research is time triangulation by comparing the data from the written answers and the data from the second interview with different time intervals. If the first and second interviews are consistent, then the interview can be stopped with the data obtained, thus invalid. If the data obtained are not consistent, then conducted a third interview and then compared the data from the first or second interview. If consistent data is obtaining between the third data with the first data or the second data, the interview data is valid.

\section{Results}

In this study, before the subject took the test, first prepared media that had been formed into several shapes of flat shapes and had been given a code of faithful shapes with letters, the media was used to reveal the subject's understanding of the rectangular shape

Subjects' responses to the interview transcripts were coded with the format $<\mathrm{R}$ - subject code $(\mathrm{xxxx})>$. $\mathrm{R}$ is the response Code subject_ task code is the problem solving task code, namely 1 for (TPMB1) (problem solving tasks interpreting, exemplifying, classifying, summarizing, inferring, comparing, and explaining), $\mathrm{x}$ is the task code solving The problem is, xxx is the three-digit serial number of the subject's response, and the subject code is the subject code, SPKS for female subjects with moderate hearing loss. For example, RSPKS1001 is the response of the female subject of TPMB1 sequence 001. Meanwhile, the interviewer code is coded $\langle$ P-subject code $(\mathrm{xxxx})\rangle$. interviewersubject code- assignment code. For example, PSPKS1001 is the subject interview on TPMB

PSPKS201 : This is a problem of building a rectangle, please read and understand what it means

RSPKS201 : Reading questions in a low voice, sometimes it is not clear how to pronounce the words while pointing at words.

PSPKS202 : Do you understand what it means

RSPKS202 : Shake his head

PSPKS203 : From this cardboard media, you are asked to point to a rectangular shape

RSPKS203 : As he observed the shape flat then take one carton media as a representation of the rectangle and give reasons why the chosen media is waking up a rectangle because it has two long sides, two sides of the width and angle brackets, as in Figure 2

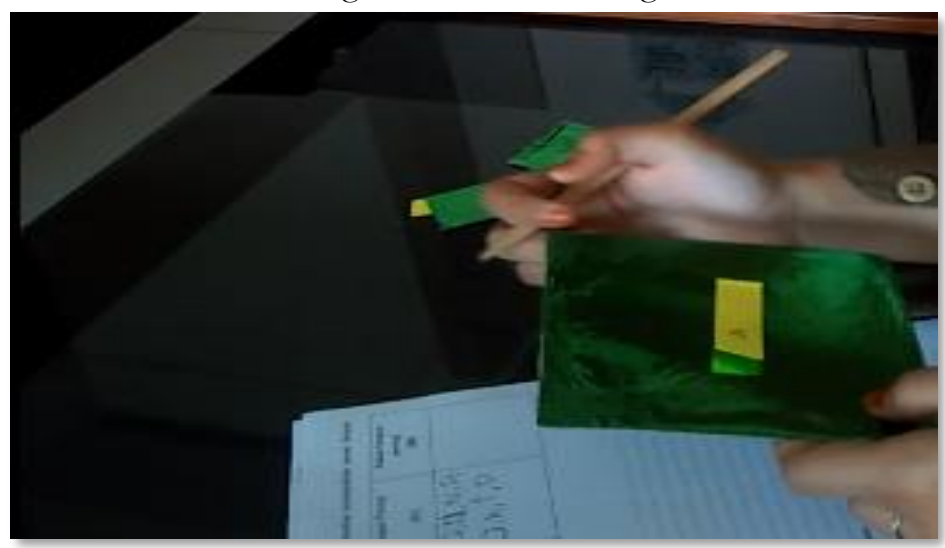

\section{Figure 2.}

Deaf Students Fill in the Column according to the Shapes that have been Held and have been Observed

PSPKS2004 : Aside from the media carton, can you find objects that resemble a rectangle shape up in the environment around you?

RSPKS2004 : Viewing surrounding objects and pointed windows, doors and frames, as shown in Figure 3. 


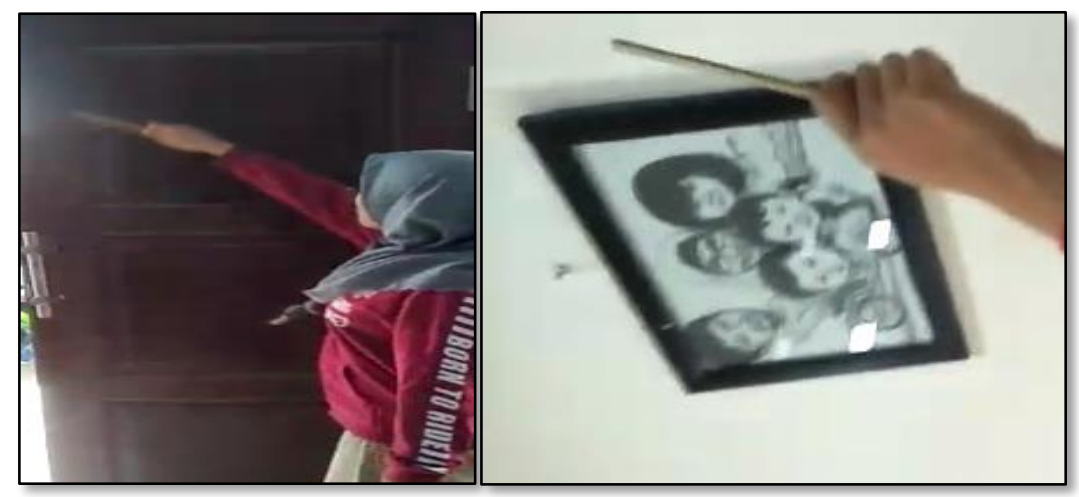

\section{Figure 3.}

Deaf Students Provide Examples

In the interpreting category, the subject understands the correct rectangular shape from cardboard after observing the various forms of four-sided shapes provided by both large and small media. Subjects also understand the surrounding objects that resemble shape rectangle with straight pointed objects around an interpretation of waking rectangle and can give a reason as in Figure 2, the subject answers in writing.

PSPKS2005 : After you find a representation of a rectangular shape from cardboard and objects in your environment, can you draw it

RSPKS2005 : Silently and then draw a rectangle model mimics the shape of media carton without using a ruler as in Figure 4.

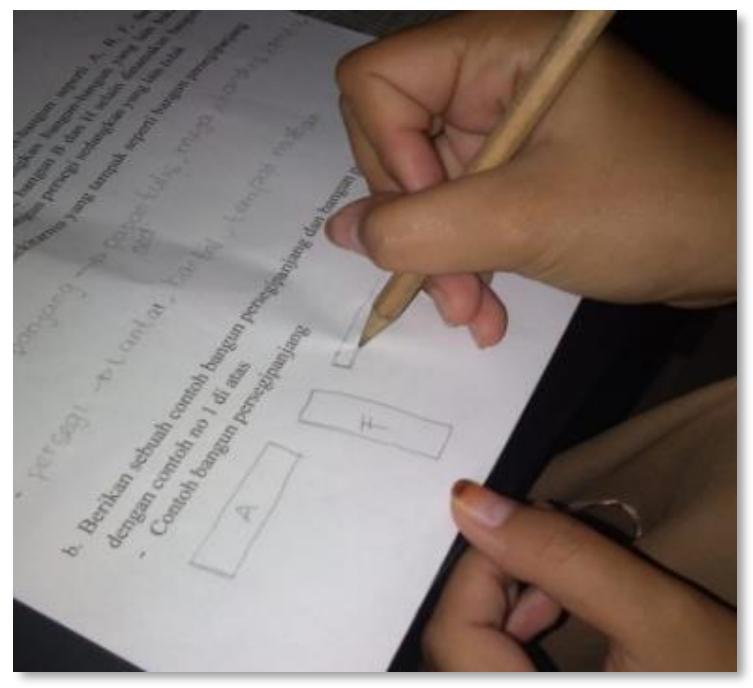

Figure 4.

Deaf Students Drawing Several Rectangular Shapes

In the exemplifying category, the subject can draw a rectangular shape without using a ruler so that after measuring the length of the sides, it is not the same. However, the subject uses the perception that the shape is rectangular because there are two long sides and two full sides.

PSPKS2007 : Now you are asked to group these flat shapes according to the name of the shape

RSPKS2007 : Yes (tinkering with the cardboard media and looking for the same shape model then grouping very carefully both in terms of shape and side length of the shapes) then write the building code in the column provided as shown in Figure 5. 


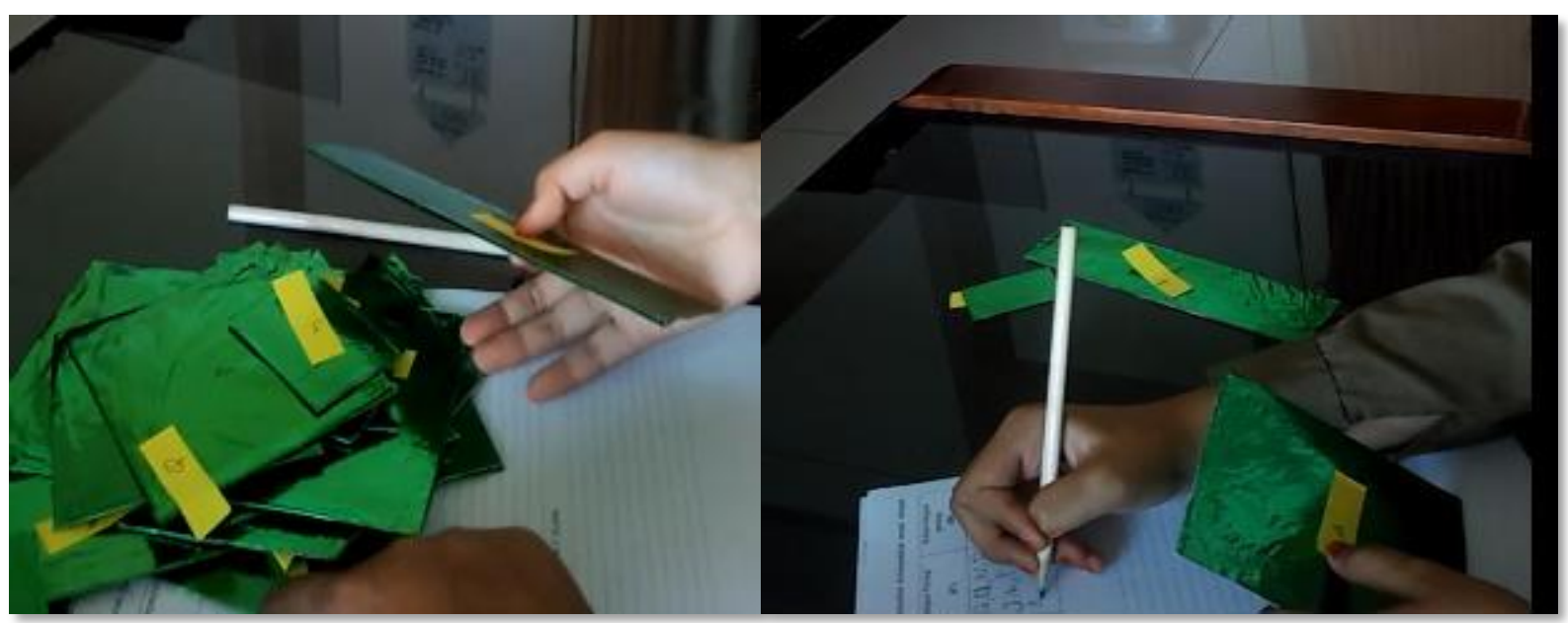

\section{Figure 5.}

Deaf Students Try to Adjust the Arrangement of Rectangular

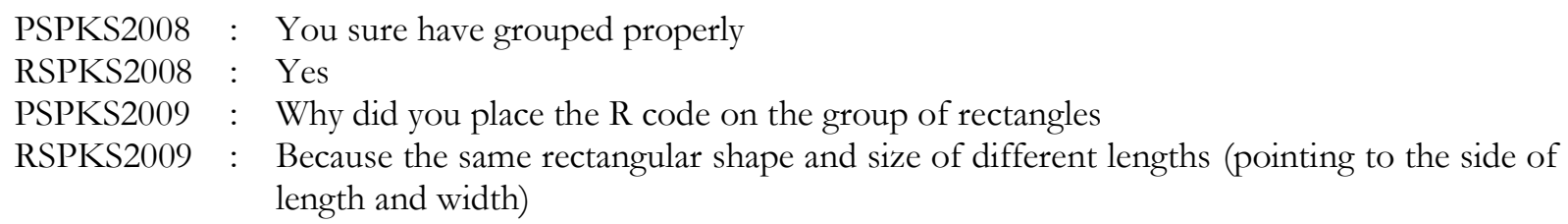
Here are answers to the subject, as in Figure 6 below

c. Diberikan sejumlah bangun yang terbuat dari karton berikut, kemualan ксıипроккаn sesuai dengan

\begin{tabular}{|l|l|l|l|}
\hline \multicolumn{1}{|c|}{$\begin{array}{c}\text { Bangun persegipanjang } \\
\text { (A) }\end{array}$} & $\begin{array}{c}\text { Bukan bangun } \\
\text { persegipanjang } \\
\text { (B) }\end{array}$ & $\begin{array}{c}\text { Bangun Persegi } \\
\text { (C) }\end{array}$ & $\begin{array}{c}\text { Bukan bangun } \\
\text { persegi } \\
\text { (D) }\end{array}$ \\
\hline$R, S, O, L, H, B, T, w, X, V, T, G$ & $Q, G, N, P, Y, W, X, V, T$, \\
$M, f$ & $E, C$, & $A, T, D$ & $G, E, C$ \\
& & $A$, & \\
\hline
\end{tabular}

\section{Figure 6.}

Answers of Deaf Students

In the classifying category, observation of the subject on the cardboard media that has been labelled with letters, she can place a rectangular erection following the name of the erection. She can give a reason why he placed the erection code.

PSPKS2010 : Previously have grouped shape was the appropriate quadrilateral in shape, get you to mention what the characteristics of the rectangular shape

RSPKS2010 : Shake his head

PSPKS2011 : Explaining the meaning of the word characteristics to the subject by giving another example, those characteristics are like you who have two eyes, a nose, wear earrings and others, now what are the characteristics of a rectangular shape

RSPKS2011 : Observing the rectangular shape media then says) say two long sides, two full sides and four right angles and write them down on the answer sheet (Figure 7 Observing the rectangular shape media) say two long sides, two full sides and four right angles and write them down on the answer sheet (Figure 7). 


\section{Figure 7.}

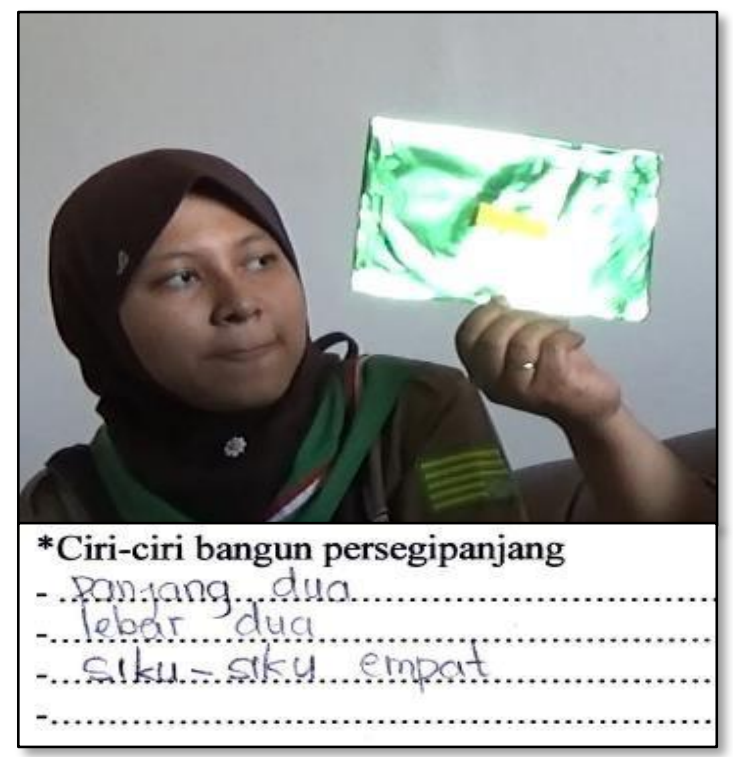

Observing the Rectangular Shape Media

PSPKS2012 : Are there other traits rectangular shape

RSPKS2012 : Looking at the rectangular-shaped cardboard media then said it was finishing In the summarizing category, after observing the cardboard media the subject mentioned rectangular features like Figure 7 above but the subject could not mention more features of a rectangular shape.

PSPKS2013 : Once you mention the shape characteristics rectangle, what is it woke a rectangular (ask definition)

RSPKS2013 : shake one's head

PSPKS2014 : Try to observe the shape of this (media holding cardboard rectangle-shaped shape) as shown in Figure 8.

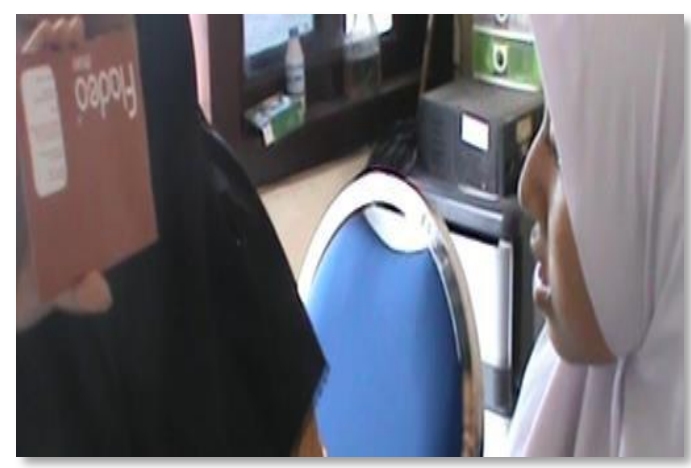

Figure 8.

Deaf Students Try to Analyze the Features of Rectangular and Square Shapes

RSPKS2014 : Said two long and two full and has four right angles (pointing to the side of the carton) as shown in Figure 9.

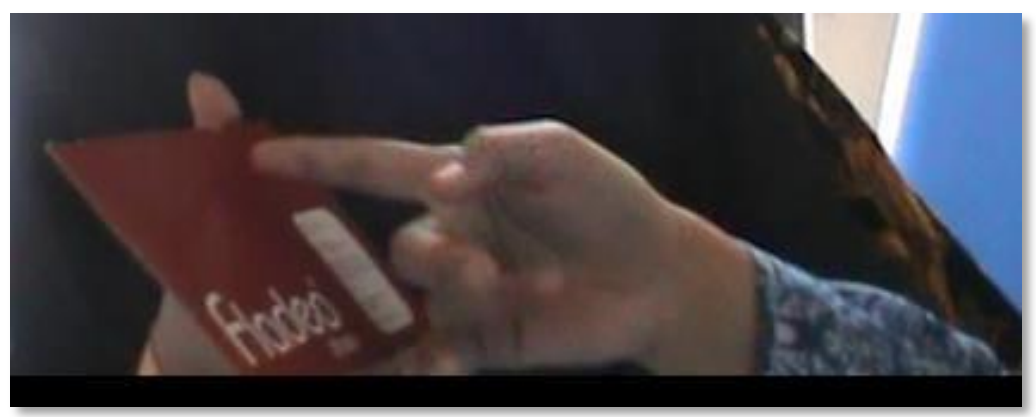

\section{Figure 9.}

Deaf Students Try to Give an Explanation 
In the inferring category, the subject does not mention the definition of a rectangular shape formally as people generally express the definition of a rectangular shape. However, the subject only points to what appears in shape
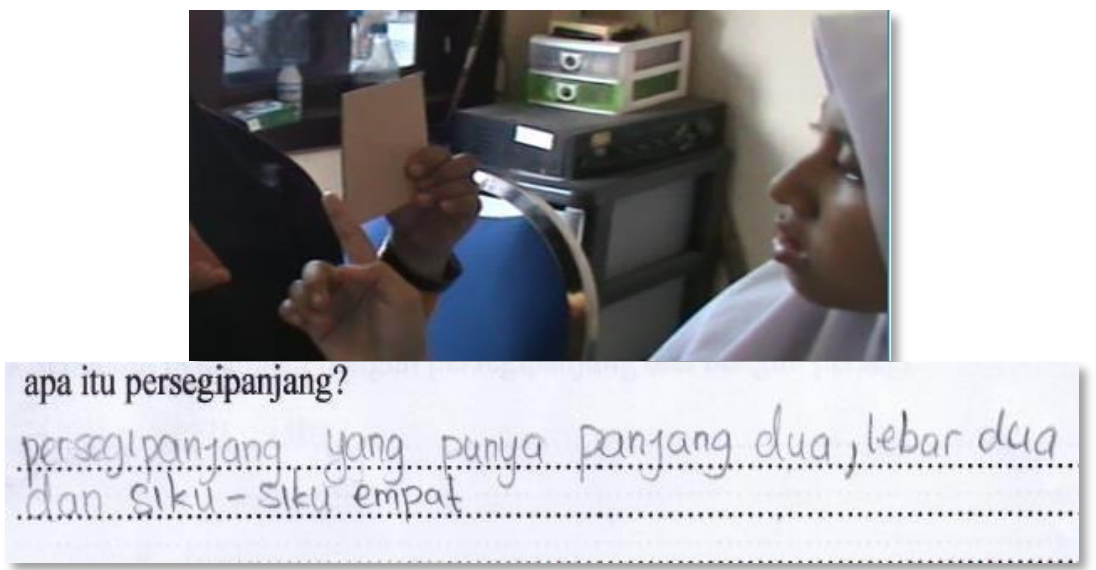

Figure 10.

Deaf Students Try to Answer Questions

PSPKS2017 : Can Deaf students analyze a parallelogram shape

RSPKS2017 : Yes, (choosing a rectangular shape) then observes and then says the equation for the two shapes has the same angle, that is right angles, while the difference is the width of the rectangle and the length of the side, as shown in Figure 11.

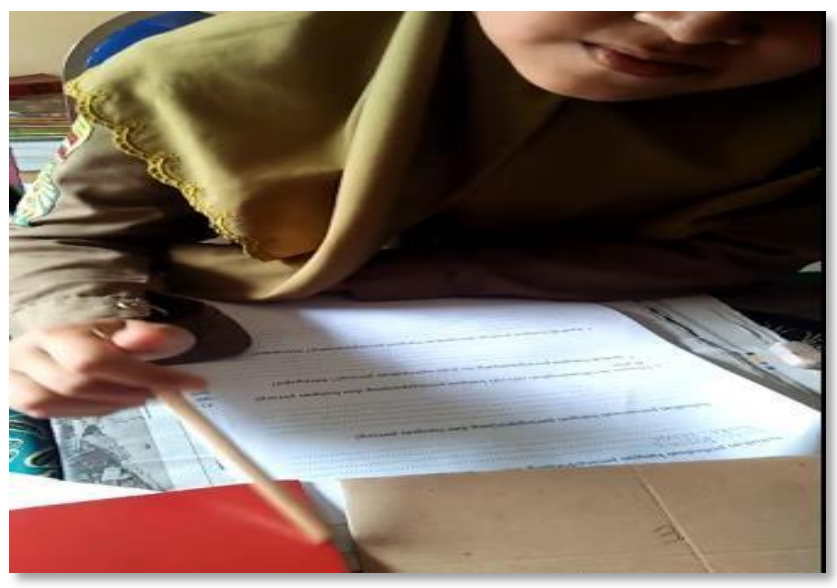

(a)

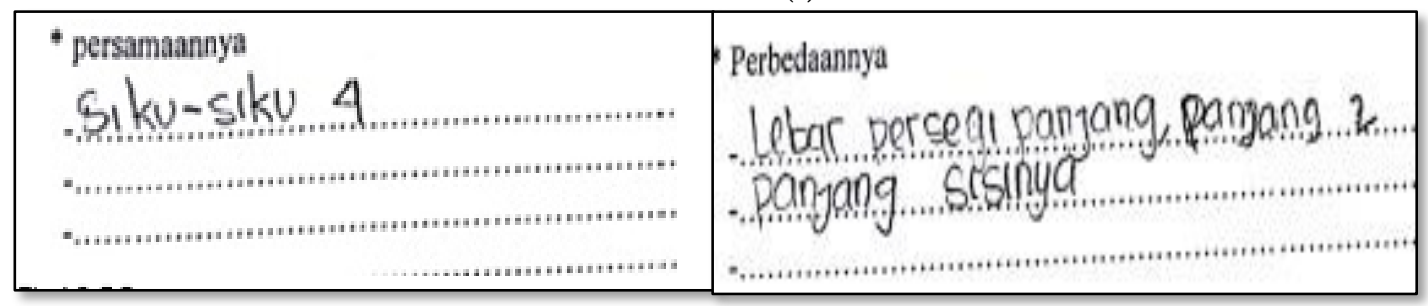

(b)

(c)

Figure 11.

(a), (b), (c)Deaf students try to answer the differences and similarities of rectangles and squares

In the comparison category, the subject observes the shape of the shape that has been selected from cardboard. The subject can mention the similarities and differences in the shapes of the sides and angles of shape. The subject is not able to find similarities and differences other than waking up that have been like on the subject answers in Figure 12.

PSPKS2018 : note shape rectangular and square shape of this whether square shape can also be said as a shaped rectangle

RSPKS2018 : (Viewing shape held by the researcher pointing to the long side of the rectangle and said shape should not be because of different length as shown in Figure 12. 


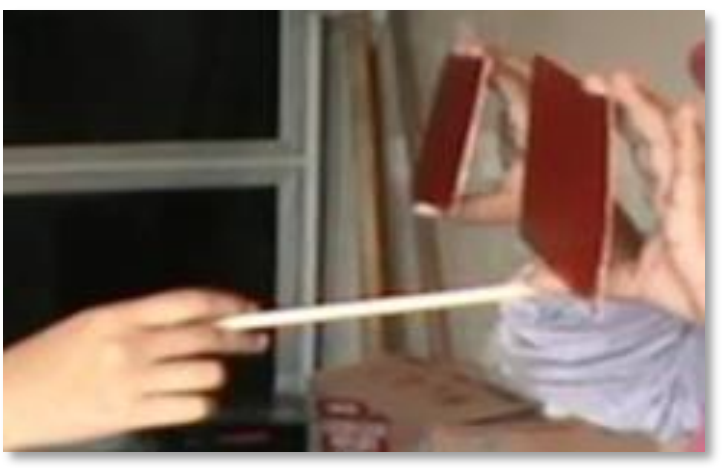

Figure 12.

Deaf Students Try to Distinguish Rectangular and Square Shapes

PSPKS2019 : Do you have any other reason apart from the different side lengths?

RSPKS2019 : That is it (shaking his head)

PSPKS2020 : If the mother changed his position whether rectangular shape waking may be called as a square? Why

RSPKS2020 : Not allowed because of the difference in size (while paying attention to the rectangular shape and the square shape held by the researcher)

The results of the interview showed that the subject of deaf students and the lowest math ability grouped the wake code with officer one even while rotating the wake rank. Before writing the code structures' in the column has been provided, the subject of deaf students being and ability lowly mathematics carefully and seemed unhurried has grouped all wake coded correctly despite the wake that the difference in length between two adjacent sides only $3 \mathrm{~mm}$ but the subject can place according to the wake code column. The subject of students with moderate deafness and low math ability stated the reason why column B and D the code is the same because the two columns are neither a rectangular shape nor a square shape. The subject of students with moderate deafness and low mathematical abilities stated the reason why he placed the coded shapes in a specific column even though one of the codes was randomly selected among the available shapes.

In explaining category, the subject found no association between a waking rectangle with a square shape but just look at the shape and size of the shape.

\section{Discussions and Conclusion}

Although the subject has to solve the problem that has been given, but based on the results described above can be understood how the subject expresses his understanding of the shapes rectangle using cardboard media. Each question subjects asked to read and understand the intent of the question, but every question followed a repeated explanation of the intent of the question. In the first category, the subject can show rectangular shapes made of cardboard and other objects in the surrounding environment. It is under what Chen (2006) said that in learning, it is essential to make mathematical concepts more visual for all students, especially deaf students. Next, using the students' visual objects more easily identify geometries based on physical appearance

In the second category, the subject can make waking image rectangular shape according to the media carton observed not only the subject using a ruler.so the size is not the same side, but the subject by using perception assumes that the image is a rectangular shape. Subject only see the shape is to overlook the size. In the third category, the subject can place the given rectangular shapes in various sizes according to the name of the shape and write it down in the corresponding column. Although there are several shapes of the same size with different sizes, the subject can still place them according to the group of shapes. Krause (2018) reports that the embodied approach and function of the means of body speech have a more considerable significance for deaf learners. At the one hand, visual signals very much form the learning process in social interaction as the language used is the visual language. In a deaf math class, maths practically need to be visual. Visual media for learning mathematics can be in the form of triangles, rectangles, circles, rulers, puzzle boards, books, pictures, and markers which are quite helpful in the learning process (Witaharap \& Surya, 2017).

In the fourth category, students identify the features of a rectangular shape based on the shape and length of the sides as well as the angular shape only. The same thing in the fifth category only mentions the same thing as in the fourth category. It is consistent with the results of research Rosich (2005), which examined three groups of students 
to compare the development of geometry using hypermedia tool, Specific difficulties in geometry. Deaf students have difficulty generalizing the characteristics of the shape. It takes longer than other students. Similarly, the results of research Husniati et al. (2019) that the deaf student's difficulty in expressing a definition shape rectangle. While in the sixth category, the subjects found the similarities and differences shape rectangles with another rectangle shape and size of a shape-up side.

In explaining category, the subject is not able to provide answers that associate a causal link between shape rectangles with square shape. In addition, the results of the investigation showed that:

a. Interpreting category: a,) SUBJECT-1 with moderate deafness and low math ability interprets two pictures of several shapes that have been given as a representation of a rectangular shape because the shape has a long line and a straight line by touching two adjacent lines. b) SUBJECT-1 with moderate hearing impairment and low mathematical skills interpret the table, window glass, door as a representation of a rectangular shape because the three images are the same shape as a rectangular shape, there are long lines while feeling the edges of the objects mentioned. c) SUBJECT-1 with moderate deafness and low mathematical skills interprets two pictures of several given shapes as a representation of a rectangular shape because the shapes mentioned are the same length of the line by pointing to two adjacent lines. d) SUBJECT-1 with low mathematical skills interprets ceramics, chair cushions, as a representation of a rectangular shape because the two objects have equal edges. e) SUBJECT-1 with low math ability interprets a food container because the lid is the same, and the outlines are the same while imagining the shape of the object mentioned.

b. Exemplifying category: a) SUBJECT, -1 female student with moderate deafness and low math ability, give an example of a rectangular shape by drawing three rectangular shapes of different sizes without using a ruler so that it appears that the lines are not straight and the angles are not exactly 90 degrees. b). SUBJECT- 1 female students with moderate deafness and low math ability give an example of a rectangular shape by drawing three squares of different sizes so that the rectangular shape does not have the same size, there is a difference between adjacent sides. c) SUBJECT-1 gave arguments why the building which paints a picture shape of rectangle or square shape using the only perception without measuring first. The shape that has been drawing is considered equal to shape rectangle and square shape and compared them to shape up an earlier picture and ignore the long-side size and shape of the shape corner.

c. Classifying category: a) SUBJECT-1 being deaf students and low math ability grouping code shape by observing one by one even while rotating position shape up before writing code that the column has been providing, b).SUBJECT-1 being deaf students and low math skills carefully and seemed unhurried has grouped all shape coded correctly. Although there are differences shape lengths between two adjacent sides only $5 \mathrm{~mm}$ the subject can be put by the shape-up code field, c). SUBJECT- 1 student with moderate deafness and low math ability argue why column $\mathrm{B}$ and $\mathrm{D}$ the code is the same because the two columns are neither a rectangular shape nor a square shape, d). SUBJECT-1, a student with moderate hearing and low math ability, states the reason why he places the coded shapes in a particular column even though one of the codes is randomly selecting among the available shapes.

d. Category summarizing: SUBJECT-1 female students with moderate deafness and low math ability before mentioning shape-up features first explain the meaning of the word traits accompanied by examples andThe demonstration then mentions and explains the characteristics of a rectangular shape, which is that it has two long sides and two full sides, and it has right angles, b) SUBJECT-1 female students with moderate deafness and low math ability do not mention other features of the rectangular shape other than those already mentioned, c) SUBJECT-1 female students with moderate hearing impairment and low math ability mention and write down the characteristics of a square shape, which has four sides of the same size and has right angles. d) SUBJECT-1 female students with moderate deafness and low math ability do not mention other features of the rectangular shape other than those already mentione

e. Inferring category: a) SUBJECT-1 before expressing the definition of a rectangular or square shape, first explain the meaning of the word definition through another object that is easy to understand and use every day by students, b) SUBJECT-1 female students with moderate deafness and low math ability mention and write the definition of a rectangular shape, which is a shape that has two lengths and two widths and a right angle, c) SUBJECT-1 female students with moderate deafness and low math ability state and write the definition of a rectangular shape, namely a shape that has four equal sides and four right angles. 
f. Category comparison: a) SUBJECT-1 female students with moderate deafness and low math ability compare the rectangular and tiered shapes by suggesting the difference between the two shapes from their side shape, namely the straight rectangular side while the sloping side of the line without revealing the equation of the two, b) SUBJECT-1 female student with moderate deafness and low math ability comparing rectangular and trapezoidal shapes with 246 suggests the difference between the two shapes from their side shapes, namely the side of the rectangular shape is straight while the side of the trapezium is tilted without expressing the equation of the two, c) SUBJECT-1 female students with moderate deafness and low math ability compare rectangular and square shapes by suggesting the equation of the angular shape while the difference is from the side length

g. Explaining category: a) SUBJECT, -1 female student with moderate deafness and low math ability, compare the rectangular and tiered shapes by suggesting the difference between the two shapes from their side shape, namely the straight side of the rectangle while the side of the line is tilted without revealing the equation of the two. b) SUBJECT - 1 female student with moderate disability and low math ability compares a square shape and a trapezoidal shape by suggesting the difference between the two shapes from their side shape, namely the side of the rectangular shape is straight. In contrast, the side of the trapezium tilted without expressing the equation of the two, c) SUBJECT-1 female students with moderate deafness and low math ability compare rectangular and square shapes by suggesting their equations from the shape of the right angles while the difference is from the side length.

Based on the achievements of each indicator, it shows that the learning outcomes for children with special needs can understand the learning provided. It is undoubtedly supporting by instructional media used. Application of appropriate media will provide a conceptual understanding of mathematics., although it requires a relatively long process. The role of the teacher as a facilitator in the learning of mathematics for students with hearing impairment would so play an important role. Some of the critical roles of teachers in helping students in the dissemination of information are the learning process (Kurniasih et al. 2020). Ayudewayani (2016) and Botting et al. (2017) explained that potentially, deaf children have the same level of intelligence as healthy children. However, several factors influence the development of intelligence, including language, limited information and children's abstraction. It is evident from the results obtained in which students understand the learning provided. It can be seen from several indicators achieved starting from the interpreting, exemplifying, classifying, summarizing inferring, comparing and explaining stages. From these indicators prove that deaf students in intelligence have the ability in mathematical terms. Khoiriyah (2018) reported in a study that deaf students have five skills in critical thinking.

Other than that from the investigation shows that the deaf students were able to identify the various forms given albeit very slowly. It is in line with Wahyuningsih's (2016) statement that proving, creating or looking for a mathematical pattern is something that requires a process. It process requires individual guidance and education in order to develop the potential of the child as optimally as possible (Pratama et al. 2020). Its ability can be developed in the form of student representations which are useful for describing, communicating mathematical objects, solving problems in mathematics and with mathematics (Wulandari et al. 2019). A similar thing was founded in the results of investigating student activities in Figure 4 and Figure 6 which were able to represent observed mathematical objects. Mathematical symbols students can use to perform a series of calculations and facilitate students in solving problems, one of which allows students to be able to represent what they think. The form of verbal representation is using under what students understand based on public information. Representation, verbal and written, can help teachers understand how students learn and how to use the language of mathematics (Zhe, 2012; Sealey et al. 2014).

Each deaf student has different representations in solving mathematical problems (Praditya et al. 2018). Therefore, knowing the results of the interpretation of students' thoughts in terms of how these students represent and solve the given mathematical problems can support the selection of strategies or methods used in learning. Selection of the proper strategy or method will facilitate the learning process as well as being useful, and learning objectives can be achieved (Rois \& Astina, 2018). It shows that it is necessary to know how the mathematical representation of students in solving mathematical problems. In the education world, not many people know the interpretation of special needs students in solving mathematical problems (Hermanto, 2018). In general, what is known is how students with special needs communicate daily. Knowing how the mathematical representation of students with special needs is a new challenge in education to be able to achieve learning goals like students in other public schools. 
From the results that have been described so that in general, deaf students can identify the physical form of various shapes, especially in geometric patterns so that students can group objects according to the group of shapes

\section{Recommendations}

For further studies: Further research on the understanding profile of deaf students can be developed on different types of problems or with a different topic. For further researchers, can then use the male gender of participants and be able to review how gender differences.

For applicants: Teachers in teaching geometric shapes, mainly flat rectangular and square shapes, should use image media or other media that have various sizes not only can students guess the difference in size, but the media that has a difference in the size of the adjacent sides is minimal, allowing students to think about using measuring instruments before determining the type of shape

\section{Limitations of Study}

This study was limited to the understanding of the concept of waking rectangle bounded on the subject of female participants, date and math education

\section{Acknowledgement}

The author would like to thank Direktorat Jenderal PenguatanRiset dan Pengembangan Kementerian Riset Teknologi dan Pendidikan Tinggi which have financed the authors in the study in fiscal year 2014 through 2018 through the BPP-DN scholarship program.

\section{Biodata of the Authors}

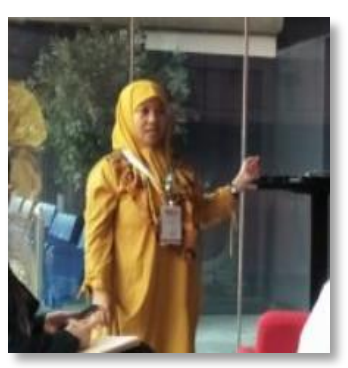

Andi Husniati, S.Pd., M.Pd. She is a Student Doctoral of Mathematics Education in State University of Surabaya and Lecturer in the Department of Mathematics Education Muhammadiyah University of Makassar. Her research is focused on Mathematic education, especially in Learning models, pedagogy, Student competence in learning. Affiliation: State University of Surabaya and Muhammadiyah University of Makassar Email: husniatia.husniati@mhs.unesa.ac.id; andihusniati@unismuh.ac.id Phone: (+62)81342462891 Orcid No: 0000-0001-6721-8256

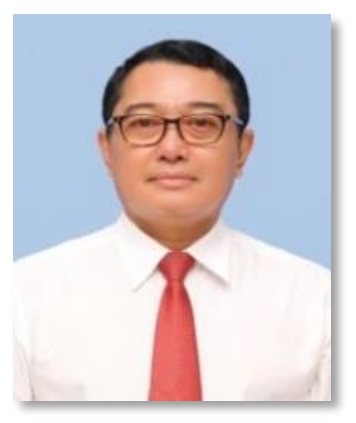

Prof. Drs. I Ketut Budayasa, P.hD. He is a Profesor and senior lecturer at State University of Surabaya, Indonesia. His research is focused on Mathematics Education, especially learning model, pedagogy, Algebra. Affiliation: Department of Mathematics Education, State University of Surabaya, Indonesia. Email: ketutbudayasa@unesa.ac.id, Phone: - Orcid No: 0000-0002-5066-859X

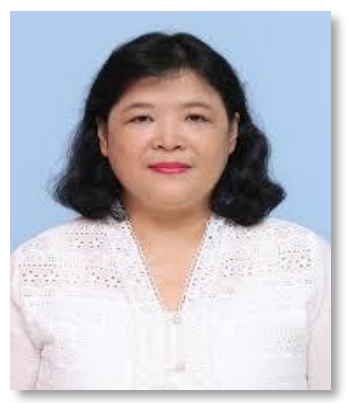

Prof. Dr. Dwi Juniati, M.Si. She graduated her doctoral program from Universite de Provence, Marseille - France in 2002. She is a professor and senior lecturer at mathematics undergraduate and doctoral program of mathematics education at Universitas Negeri Surabaya (State University of Surabaya). Her research interest are mathematics education, cognitive in learning and mathematics (Topology, Fractal and Fuzzy). Affiliation: Universitas Negeri Surabaya, Indonesia Email dwijuniati@unesa.ac.id Orcid ID: 0000-0002-5352-3708 SCOPUS ID: 57193704830 WoS Researcher ID : AAE-5214-2020 


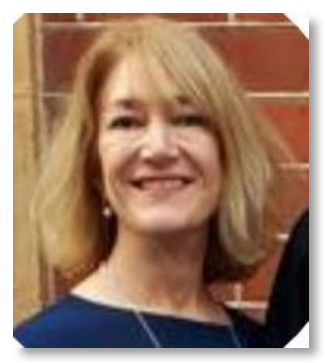

Dr Carol Le Lant. She is a lecture in the College of Education, Psychology and Social Work, Flinders University. The primary focus of my research, teaching and consultancy is on student engagement, linked explicitly with differentiating the learning experiences for all students. Drawing on evidence-based practice and research, I aim to build higher teacher capacity in both our pre-service and practising educators. Affiliation: College of Education, Psychology and Social Work, Flinders University, South Australia Phone: +61 882015684 E-mail: carol.lelant@flinders.edu.au

\section{References}

Achmetli, K., Schukajlow, S., \& Rakoczy, K. (2019). Multiple solutions for real-world problems, experience of competence and students' procedural and conceptual knowledge. International Journal of Science and Mathematics Education, 17(8), $1605-1625$.

Akram, B., Mehboob, R., Ajaz, A., \& Bashir, R. (2013). Scientific concepts of hearing and deaf students of grade VIII. Journal of Elementary education, 23(1), 1-12.

Akuba, S. F., Purnamasari, D., \& Firdaus, R. (2020). Pengaruh kemampuan penalaran, efikasi diri dan kemampuan memecahkan masalah terhadap penguasaan konsep matematika[Effect of reasoning skills, self-efficacy and problem solving skills to mastery of mathematical concepts]. JNPM (Jurnal Nasional Pendidikan Matematika), 4(1), 44-60.

Anggraeni, S. T., Muryaningsih, S., \&Ernawati, A. (2020). Analisis factor penyebab kesulitan belajar matematika di sekolah dasar[Analysis of factors causing difficulty in learning mathematics in elementary schools]. JurnalRiset Pendidikan Dasar (JRPD), 1(1).

Ayu Dewayani, D. (2016). Model Pembelajaran Think Talk Write (Ttw) Terhadap Hasil Belajarpemecahan Soal Cerita Bilangan Bulat Matematika Siswa Tunarungu LLearning Model Think Talk Write (TTW) Toward Learning Results Problem Solving Integer Math Story Deaf Students]. Jurnal Pendidikan Khusus, 8(1).

Beller, M., \& Gafni, N. (2000). Can item format (multiple choice vs. open-ended) account for gender differences in mathematics achievement?. Sex roles, 42(1-2), 1-21.

Botting, N., Jones, A., Marshall, C., Denmark, T., Atkinson, J., \& Morgan, G. (2017). Nonverbal executive function is mediated by language: A study of deaf and hearing children. Child Development, 88(5), 1689-1700.

Chen, K. (2006). Math in motion: Origami math for students who are deaf and hard of hearing. Journal of deaf studies and deaf education, $11(2), 262-266$.

Clements, D. H. (2004). Geometric and spatial thinking in early childhood education. Engaging young children in mathematics: Standards for early childhood mathematics education, 267-297.

Curto Prieto, M., Orcos Palma, L., BlázquezTobías, P. J., \& León, F. J. M. (2019). Student assessment of the use of Kahoot in the learning process of science and mathematics. Education Sciences, 9(1), 55.

Dewi, S. (2020). Proses kontruksi pengetahuan siswa ditinjau dari gaya kognitif field dependent pada pelajaran matematika di SMA negeri 8 kota Jambi [The process of students' knowledge construction in terms of the field dependent cognitive style in mathematics lessons at SMA Negeri 8 Jambi City]. PHI: Jurnal Pendidikan Matematika, 4(1), 55-64.

Duffin \& Simpson,2002 :A Search for understanding. School of Mathematics, University of Hull, Hull, HU6 7RX, UK Mathematics Education Research Centre, Institute of Education,University of Warwick, Coventry, CV4 7AL, U.K

Else-Quest, N. M., Hyde, J. S., \& Linn, M. C. (2010). Cross-national patterns of gender differences in mathematics: a metaanalysis. Psychological bulletin, 136(1), 103.

Ghani, A. A., \& Zulkarnaen, R. (2020). Studi kasus tingkat berpikir geometri siswa SMP berdasarkanTeori Van Hiele[A case study on the geometric thinking level of junior high school students based on Van Hiele's theory]. ProsidingSesiomadika, 2(1e).

Giménez, J., \& Rosich Sala, N. (2007). Improving geometry by using dialogic hypermedia tools: A case study. Interactive Educational Multimedia, 2007, num. 14, p. 65-64.

Hergovich, A., Sirsch, U., \& Felinger, M. (2004). Gender differences in the self-concept of preadolescent children. School Psychology International, 25(2), 207-222.

Hermanto, H. (2008). Kemampuan guru dalam melakukan identifikasi anak berkebutuhan khusus di sekolah dasar penyelenggara pendidikan inklusi. Yogyakarta: Yogyakarta State University.

Husniati, A., Budayasa, K., Juniati, D., \& Akib, I. (2019, March). Understanding hearing impairment students at SMPLB in rectangle based gender. In Journal of Physics: Conference Series (Vol. 1188, No. 1, p. 012077). IOP Publishing.

Khoiriyah, S. (2018, July). Analisis Kemampuan Berfikir Kritis Matematika pada Siswa Tunarungu di Sekolah Luar Biasa (SLB) Negeri Pringsewu [Analysis of Mathematical Critical Thinking Ability of Deaf Students in Pringsewu State Special School (SLB)]. In Prosiding Seminar Nasional Matematika dan Pendidikan Matematika (Vol. 1, No. 2, pp. 375-378).

Krause, C. M. (2018). Embodied geometry: Signs and gestures used in the deaf mathematics classroom-The case of symmetry. In Mathematical discourse that breaks barriers and creates space for marginalized learners (pp. 171-194). Brill Sense.

Kurniasih, M. D., Darojati, H., Waluya, S. B., \& Rochmad, R. (2020). Analisis Gesture Siswa Tunarungu dalam Belajar Matematika di Tinjau dari Gender [Analysis gestures Deaf Students in Math Seen From Gender]. JKPM (Jurnal Kajian Pendidikan Matematika), 5(2), 175-182. 
Ling, C. Y., Osman, S., Daud, M. F., \&Hussin, W. N. W. (2019). Application of Vee Diagram as a problem-solving strategy in developing students' conceptual a nd procedural knowledge. International Journal of Innovative Technology and Exploring Engineering (IJITEE), 8(10), 2796-2800.

Miles, M.B., \& Huberman A. M. 1994. Qualitative data analysis. Second Edition. USA: The United States of America

Misu, L., Budayasa, I. K., Lukito, A., \& Rosdiana, R. (2019). Comparison of metacognition awareness of mathematics and mathematics education students based on the ability of mathematics. International Journal of Trends in Mathematics Education Research, 2(3), 124-127.

Mudjiyanto, B. (2018). Pola komunikasi siswa tunarungu di sekolah luar biasa negeri bagian B Kota Jayapura [Communication patterns deaf students at a special school country Jayapura City section B7. Jurnal Studi Komunikasi Dan Media, 22(2), 151-166.

Ningsih, T, S., Abdurahman, Mardapi, J., \& Fayanto, S. (2019). Study on the Effect of CORE (connecting, organizing, reflecting and extending) learning model on mathematics learning outcomes of cognitive domain. Universal Journal of Educational Research,7(11), 2463-2471. DOI: 10.13189/ujer.2019.071125

Pratama, Y., Dwirahayu, G., \& Satriawati, G. (2020). Analisis penerapan model inquiry dalam pembelajaran matematika di SLB 4 Jakarta [Analysis of the application of mathematical models of inquiry learning in SLB 4 Jakarta]. Algoritma Journal of Mathematics Education, 2(1).

Praditya, P. A. D., Sudarma, I. K., \& Pudjawan, K. (2018). Pengembangan multimedia pembelajaran dengan evaluasi instructional game matematika siswa kelas VII-SMPLB Negeri 1 Buleleng[The development of multimedia learning by evaluating the instructional game mathematics of class VII-SMPLB Negeri 1 Buleleng students]. Jurnal Edutech Undiksha, 6(1), 66-76.

Raghubar, K. P., Barnes, M. A., \& Hecht, S. A. (2010). Working memory and mathematics: A review of developmental, individual difference, and cognitive approaches. Learning and individual differences, 20(2), 110-122.

Rois, A., \& Astina, C. (2018). Implementasi metode maternal reflektif dalam pembelajaran bahasa arab bagi anak tuna rungu di SLB Purwosari Kudus [Implementation of reflective maternal methods in learning Arabic for deaf children at SLB Purwosari Kudus]. Jurnal Penelitian dan Pengabdian Kepada Masyarakat UNSIQ, 5(3), 372-387.

Rosdiana, M., Budayasa, I. K., \&Lukito, A. (2019, April). Female students' reasoning of primary school teacher education in solving geometry problems. In $1_{\text {st }}$ International Conference on Advanced Multidisciplinary Research (ICAMR 2018). Atlantis Press.

Rosdiana, R., Budayasa, I. K., \& Lukito, A. (2019). Pre-service primary school teachers' mathematical reasoning skills from gender perspectives: a case study. Journal for the Education of Gifted Young Scientists, 7(4), 1107-1122.

Sealey, V., Deshler, J. M., \& Hazen, K. (2014). Strengthening student understanding of mathematical language through verbal and written representations of the intermediate value theorem. PRIMUS, 24(2), 175-190.

Skemp, R. R. (1976). Relational understanding and instrumental understanding. Mathematics teaching, 77(1), 20-26.

Tahmir, S., Ja'faruddin, J., \& Abbas, N. F. (2019). Deskripsi Pemahaman geometri siswa SMP pada materi segi empat berdasarkan teori van hiele ditinjau dari gaya kognitif siswa [Description of Junior high school students 'understanding of geometry on rectangular material based on van hiele theory in terms of students' cognitive styles]. Issues in Mathematics Education (IMED), 2(1), 23-34.

Wahyuningsih, S. (2016). Analisis Cara Menyelesaikan Masalah Matematika pada Anak Berkebutuhan Khusus di Sekolah Luar Biasa [Analysis Method Math Solving Problems in Children with Special Needs in Schools]. Ekuivalen-Pendidikan Matematika, 20(2).

WitaHarahap, L., \& Surya, E. (2017). Development of Learning Media in Mathematics for Students with Special Needs. International Journal of Sciences: Basic and Applied Research (IJSBAR), 33(3), 1-12.

Wulandari, E. D., Hidayanto, E., \& Rahardi, R. (2019). Representasi Matematis Siswa Tuna Rungu dalam Menyelesaikan Soal Cerita Matematika [Mathematical Representation of Deaf Students in Math Story Problem Solving]. Jurnal Pendidikan: Teori, Penelitian, dan Pengembangan, 4(7), 971-978.

Yuliana, W. D., Mahardhani, A. J., \&Utami, P. S. (2019). Pola pendidikan karakter kemandirian anakber kebutuhan khusus tunanetra pada panti asuhan tunanetra terpadu Aisyiyah Ponorogo [The pattern of character education for the autonomy of children with special needs with visual impairments in an integrated blind orphanage Aisyiyah Ponorogo]. Edupedia, 3(1), 3947.

Zhe, L. (2012). Survey of primary students' mathematical representation status and study on the teaching model of mathematical representation. Journal of Mathematics education, 5(1), 63-76. 